\title{
PENGARUH PENGETAHUAN PAJAK, SANKSI PAJAK TERHADAP KEPATUHAN PAJAK PADA UMKM YANG ADA DI KOTA MEDAN
}

\begin{abstract}
Penulis:
Hantono

Riko Fridolend

Sianturi $^{2}$

Afiliasi:

Universitas Pelita

Harapan Medan (UPH)

Medan $^{1}$

Universitas Prima

Indonesia (UNPRI)

Medan $^{2}$

Korespondensi:

hantono_78@yahoo.com

fridolend03@gmail.com

Histori Naskah:

Submit: 99-00-9999

Accepted: 99-00-9999

Published: 99-00-9999

Abstrak:

Penelitian ini bertujuan untuk melihat pengaruh Pengetahuan Pajak, Sanksi Pajak dan Kepatuhan Pajak. Teknik pengumpulan data dengan menyebarkan kuisioner, sedangkan metode analis data yang digunakan adalah Statistik inferensial, (statistic induktif atau statistic probabilitas), adalah teknik statistik yang digunakan untuk menganalisis data sampel dan hasilnya diberlakukan untuk populasi (Sugiyono dalam Kalnadi 2013). Sesuai dengan hipotesis yang telah dirumuskan, maka dalam penelitian ini analisis data statistik inferensial diukur dengan menggunakan software SmartPLS (Partial Least Square) mulai dari pengukuran model (outer model), Hasil penelitian diperoleh Nilai thitung untuk Pengetahuan Pajak $\left(\mathrm{X}_{1}\right)$ lebih kecil dan nilai sig t untuk Pengetahuan Pajak $\left(\mathrm{X}_{1}\right)$ sebesar 0,124 lebih besar dari alpha $(0,05)$. Berdasarkan hasil yang diperoleh maka menerima $\mathrm{H}_{0}$ dan menolak $\mathrm{H}_{1}$ untuk Pengetahuan Pajak $\left(\mathrm{X}_{1}\right)$. Dengan demikian, secara parsial Pengetahuan Pajak $\left(\mathrm{X}_{1}\right)$ tidak berpengaruh positif dan tidak signifikan terhadap Kepatuhan Pajak (Y), menunjukkan Pengetahuan Pajak $\left(\mathrm{X}_{1}\right)$ tidak memberikan dampak positif dalam meningkatkan Kepatuhan Pajak (Y). Hasil penelitian diperoleh nilai thitung untuk Sanksi Pajak $\left(\mathrm{X}_{2}\right)$ sebesar 2,759 lebih besar demgan nilai sig t untuk Sanksi Pajak $\left(\mathrm{X}_{2}\right)$ sebesar 0,007 lebih kecil dari alpha $(0,05)$. Berdasarkan hasil yang diperoleh maka menolak $\mathrm{H}_{0}$ dan menerima $\mathrm{H}_{1}$. Dengan demikian secara parsial Sanksi Pajak $\left(\mathrm{X}_{2}\right)$ berpengaruh positif dan signifikan terhadap Kepatuhan Pajak $(\mathrm{Y})$, artinya Sanksi Pajak $\left(\mathrm{X}_{2}\right)$ memberikan dampak yang nyata dalam meningkatkan Kepatuhan Pajak (Y).
\end{abstract}

\section{Kata kunci: Pengetahuan Pajak, Sanksi Pajak dan Kepatuhan Pajak}

\section{Pendahuluan}

Pajak adalah kontribusi wajib kepada negara yang terutang oleh pribadi atau badan yang bersifat memaksa berdasarkan undang-undang, engan tidak mendapatkan imbalan secara langsung dan digunakan untuk keperluan negara bagi sebesar-besarnya kemakmuran rakyat.Pajak merupakan sumber penerimaan negara terbesar.Penerimaan pajak sangat penting karena pajak digunakan untuk pembangunan negara, pemenuhan kebutuhan blanja negara, dan sebagai pengatur keseimbangan perekonomian seperti mengatasi inflasi maupun deflasi.

Dalam hal meningkatkan kepatuhan UMKM dalam membayar pajak pemerintah juga telah menyediakan sanksi perpajakan bagi wajib pajak yang tidak membayar pajak.Landasan hukum mengenai sanksi perpajakan diatur dalam masing-masing pasal Undang-Undang Ketentuan Umum Perpajakan.Sanksi perpajakan dapat dijatuhkan apabila wajib pajak melakukan pelanggaran terutama atas kewajiban yang ditentukan dalam Undang-undang Ketentuan Umum Perpajakan.Dengan adanya undang-undang yang mengatur ketentuan umum serta tata cara perpajakan, dimana wajib pajak harus melaksanakan peraturan tersebut. Jika peraturan tidak dilaksanakan dengan baik atau bahkan dilanggar maka harus ada sanksi yang 
dikenakan untuk menimbulkan efek jera pada wajib pajak.Untuk mencegah ketidakpatuhan serta untuk mendorong wajib pajak untuk memenuhi kewajiban perpajakannya maka haruslah diberikan sanksi yang tegas dalam rangka untuk memajukan keadilan dan efektivitas sistem.

Direktorat Jenderal Pajak menyatakan bahwa kepatuhan perpajakan adalah tingkat di mana wajib pajak mematuhi undang-undang dan administrasi perpajakan tanpa perlunya kegiatan penegakan hukum.Tetapi permasalahan yang sering terjadi yakni banyaknya masyarakat yang tidak dapat memenuhi kewajiban perpajakannya, sehingga tingkat kepatuhan wajib pajak yang terdaftar untuk memenuhi kewajiban perpajakannya di Indonesia masih rendah.

\section{Studi Literatur}

\section{Pengetahuan Pajak}

Rahayu (2010) di dalam (Taufik \& Afiyanti , 2018), tingkat pengetahuan pajak masyarakat yang menmadai, akan mudah bagi wajib pajak untuk patuh pada peraturan perpajakan. Dengan mengutamakan kepentingan negara diatas kepentingan pribadi akan memberikan keikhlasan masyarakat untuk patuh dalam kewajiban perpajakannya.

Menurut (Mulyati \& Ismanto, 2021), pengetahuan perpajakan atau pemahaman perpajakan yang dimiliki oleh Wajib Pajak harus meliputi:

1. Pengetahuan mengenai Ketentuan Umum dan Tata Cara Perpajakan.

2. Pengetahuan mengenai sistem perpajakan di Indonesia

3. Pengetahuan mengenai fungsi perpajakan.

Wajib pajak akan meningkat seiring bertambahnya pengetahuan pajak seseorang karena dengan pengetahuan pajak yang tinggi para wajib pajak sadar akan kewajibannya dan tahu akan akibatnya jika tidak memenuhi kewajibannya(Hertati, 2021).Pengetahuan perpajakan adalah informasi pajak yang dapat digunakan wajib pajak sebagai dasar untuk bertindak, mengambil keputusan dan untuk menempuh arah atau strategi tertentu sehubungan dengan pelaksanaan hak dan kewajibannya di bidang perpajakan(Kartikasari \& Yadnyana, 2020).

Pengetahuan perpajakan adalah segala sesuatu yang diketahui, kepandaian dan segala sesuatu yang diketahui berkenaan dengan segala hal yang menyangkut tentang perpajakan.(Mumu et al., 2020).

\section{Sanksi Pajak}

Sanksi pajak dikenakan pada seorang wajib pajak bila melakukan keterlambatan atau pelanggaran.Seperti yang telah dijabarkan sebelumnya, ada dua macam sanksi dalam pajak yaitu sanksi administrasi dan sanksi pidana.Sanksi administrasi adalah sanksi yang dikenakan dengan melakukan pembayaran kerugian finansial pada negara karena pelaksanaan ketentuan peraturan perundang - undangan tidak sebagaimana mestinya. Sedangkan sanksi pidana merupakan siksaan atau penderitaan dan benteng hukum agar norma perpajakan dipatuhi(Supriatiningsih \& Jamil, 2021). Menurut (Mulyati \& Ismanto, 2021), adapun Indikator dari sanksi perpajakan, yaitu:

1. Keterlambatan melaporkan dan membayarkan pajak harus dikenai sanksi

2. Tingkat penerapan sanksi

3. Sanksi digunakan untuk meningkatkan kepatuhan Wajib Pajak

4. Penghapusan sanksi meningkatkan kepatuhan Wajib Pajak.

Sanksi pajak merupakan salah satu faktor yang dapat mempengaruhi kepatuhan wajib pajak dalam membayar pajak, karena fungsi pajak adalah sebagai alat untuk mengatur sekelompok orang untuk memenuhi aturan yang telah ditetapkan.Sanksi pajak diperuntukan kepada wajib pajak yang melanggar peraturan perpajakan yang berlaku sekarang.(Yuliansyah et al., 2019).Sanksi perpajakan merupakan jaminan bahwa ketentuan peraturan perundang-undangan perpajakan akan dipatuhi. Dengan kata lain, sanksi perpajakan merupakan alat pencegah agar wajib pajak tidak melanggar norma perpajakan(Juwita \& Wasif, 2020). Menurut Mardiasmo (2016) di dalam (Wulandari, 2020), 


\section{- 1 - Jurnal Audit \& Perpajakan}

Volume : 1 | Nomor 1 | November 2021 | E-ISSN : 2809-1809. | DOI: 10.47709/jap.v1n1.1176

sanksi pajak adalah merupakan alat pencegahan supaya WP tidak melanggar regulasi ataupun norma perpajakan.

\section{Kepatuhan Pajak}

Direktorat Jenderal Pajak menyatakan bahwa kepatuhan perpajakan adalah tingkat di mana wajib pajak mematuhi undang-undang dan administrasi perpajakan tanpa perlunya kegiatan penegakan hukum.Tetapi permasalahan yang sering terjadi yakni banyaknya masyarakat yang tidak dapat memenuhi kewajiban perpajakannya, sehingga tingkat kepatuhan wajib pajak yang terdaftar untuk memenuhi kewajiban perpajakannya di Indonesia masih rendah. Keputusan Menteri Keuangan No. 544/KMK.04/2000 menyatakan bahwa kriteria wajib pajak yang patuh adalah sebagai berikut :

a. Tepat waktu dalam penyampaian SPT untuk semua jenis pajak dalam satu tahun.

b. Tidak mempunyai tunggakan untuk semua jenis pajak.

c. Tidak pernah dijatuhi hukuman karena melakukan tindak pidana dalam bidang pajak selama 1015 tahun.

d. Dalam dua tahun terakhir menyelenggarakan pembukuan yang memadai dan telah dilakukan pemeriksaan. Koreksi pada pemeriksaan yang terakhir untuk jenis pajak terutang paling banyak $5 \%$.

e. Wajib Pajak yang laporan keuangannya dalam dua tahun terakhir diaudit dengan pendapat wajar tanpa pengecualian atau wajar dengan pengecualian tidak mempengaruhi laba rugi fiskal.

Menurut Andinata (2015) di dalam (Wulandari, 2020), kepatuhan pajak memiliki dua sudut pengertian yang berbeda. Yang pertama dari segi sederhana yaitu keterkaitan WP dalam pemenuhan kewajiban pajaknya sesuai regulasi yang berlaku.Yang kedua ialah segi komprehensif sikap rasa tanggung jawab seorang WP dan kesadaran sebagai warga negara.

Kepatuhan perpajakan diartikan sebagai suatu keadaan yang mana wajib pajak patuh dan mempunyai kesadaran dalam memenuhi kewajiban perpajakan(Yuliansyah et al., 2019).

Menurut (Erica, 2021), secara umum ada 4 (empat) indikator atas kepatuhan pajak, yaitu:

a. Kepatuhan Wajib Pajak (WP) dalam mendaftarkan diri

b. Kepatuhan Wajib Pajak(WP) untuk dapat menyetorkan kembali Surat Pemberitahuan (SPT) secara tepat waktu

c. Kepatuhan atas penghitungan dan pembayaran pajak yang terutang dari penghasilan yang diperoleh oleh Wajib Pajak (WP)

d. Kepatuhan dari Wajib Pajak (WP) atas pembayaran dari tunggakan pajaknya baik itu pada Surat Tagihan Pajak (STP) ataupun Surat Ketetapan Pajak (SKP).

Kepatuhan Wajib Pajak adalah ketika Wajib Pajak dapat memenuhi semua kewajiban perpajakannya meliputi mendaftarkan diri, menghitung dan membayar pajak terutang, membayar tunggakan dan menyetorkan kembali surat pemberitahuan (Arrozi \& Rahayu, 2021).

\section{Pengaruh Pengetahuan PajakTerhadap Kepatuhan Pajak}

The higher the level of understanding of tax provisions, the better the implementation of tax obligations as for increasing compliance. This is reasonable because often taxpayers do not carry out their tax obligations properly not because of a desire to disobey, but the complexity of taxation sometimes forces them to disobey (passive tax resistance).(Triandani \& Apollo, 2020). Semakin besar tingkat pengetahuan wajib pajak, maka semakin rendah tingkat kepatuhan wajib pajak (Arfah \& Aditama, 2020).Tingkat pemahaman wajib pajak dalam kaitannya dengan aturan pajak ditunjukkan untuk meningkatkan tingkat kepatuhan dengan persyaratan wajib pajak. Wajib pajak yang memiliki tingkat pemahaman pajak yang tinggi menunjukkan bahwa wajib pajak sangat penting untuk pembangunan infrastuktur negara(Aqiila et al., 2021).Semakin banyaknya pengetahuan perpajakan yang diketahui oleh wajib pajak maka semakin tinggi kesadaran yang dimiliki wajib pajak sehingga dapat meningkatkan kepatuhan wajib pajak dalam memenuhi kewajiban perpajakannya, sebaliknya jika semakin sedikit pengetahuan perpajakan yang diperoleh wajib pajak maka semakin rendah pula 
kesadaran wajib pajak sehingga dapat menurunkan kepatuhan wajib pajak dalam memenuhi kewajiban perpajakannya(Mulyati \& Ismanto, 2021).Semakin meningkat pengetahuan perpajakan maka akan meningkatkan kepatuhan wajib pajak. Hal ini menunjukkan bahwa semakin baik pengetahuan perpajakan wajib pajak maka akan meningkatkan kepatuhan wajib pajak(Soda et al., 2021). Semakin tinggi tingkat pengetahuan perpajakan maka tingkat kepatuhan wajib pajak semakin meningkat pula(Kartikasari \& Yadnyana, 2020).Apabila pemahaman wajib pajak terhadap perpajakan sudah tinggi maka dapat berpengaruh terhadap kepatuhan dan penerimaan dikarenakan wajib pajak sudah membayar pajak sehingga telah memberikan kontribusinya untuk pembangunan serta penunjang kesejahteraan masyarakat(Tikupadang \& Palalangan, 2020).Semakin tinggi tingkat pengetahuan wajib pajak mengenai peraturan perapajakan maka akan semakin tinggi tingkat kepatuhan pajaknya(Ayu \& Hani, 2021).

6. Pengaruh Sanksi Pajak Terhadap Kepatuhan Pajak

Dengan adanya pengenaan sanksi pajak akan dapat meningkatkan kesadaran hak dan kewajiban wajib pajakserta meningkatkan kepatuhan wajib pajak dalam kewajiban perpajakannya(Ayu \& Hani, 2021).Sanksi yang diberikan kepada wajib pajak akan membuat wajib pajak mentaati atau mematuhi peraturan perpajakan sehingga denganadanya kekuatan hukum akan sanksi yang diberikan biasanya akan membuat masyarakat semakin patuh dan menimbulkan rasa takut akan hukuman yang diberikan(Hazmi et al., 2020).Semakin tinggi sanksi pajak akan membuat Kepatuhan Wajib Pajak semakin meningkat dikarenakan sanksi yang diberikan karena pelanggaran yang telah dibuat oleh Wajib Pajak membuat Wajib Pajak jera maka mendorong Wajib Pajak untuk lebih patuh(Chandra \& Sandra, 2020).Kepatuhan perpajakan dapat timbul dengan memberikan sanksi pajak yang tegas bagi wajib pajak yang melanggar. Wajib pajak akan memenuhi kewajiban perpajakan apabila memandang bahwa sanksi denda akan lebih banyak merugikannya. Semakin banyak sisa tunggakan yang masih harus dibayar oleh wajib pajak, maka semakin berat wajib pajak untuk melunasinya.(Adhimatra \& Noviari, 2018).Wajib pajak yang memiliki pemahaman atas sanksi pajak yang tinggi, maka pelanggaran yang dilakukan oleh wajib pajak akan berkurang, maka kepatuhan wajib pajak untuk memenuhi kewajiban dalam membayar pajak akan meningkat. Sanksi pajak membuat wajib pajak berpikir jika tidak membayar pajak maka akan dikenakan sanksi pajak, dengan diterapkannya sanksi pajak tersebut akan membuat wajib pajak patuh untuk membayar pajak(Mumu et al., 2020).

\section{Metode Penelitian}

Penelitian yang diteliti bertujuan dalam menguji pengaruh antaraPengetahuan Pajak dan Sanksi Pajak Terhadap Kepatuhan Pajak .Variabel independen yang dipakai adalah Pengetahuan Pajak dan Sanksi Pajak.Variabel dependen yang dipakai adalah Kepatuhan Pajak.Teknik pengambilan data yang digunakan dalam penelitian ini, adalah melalui penelitian kepustakaan dan penelitian lapangan. Penelitian yang diteliti bertujuan dalam menguji pengaruh antara Pengetahuan Pajak dan Sanksi Pajak Terhadap Kepatuhan Pajak . Variabel independen yang dipakai adalah Pengetahuan Pajak dan Sanksi Pajak. Variabel dependen yang dipakai adalah Kepatuhan Pajak. Teknik pengambilan data yang digunakan dalam penelitian ini, adalah melalui penelitian kepustakaan dan penelitian lapangan. Data yang digunakan dalam penelitian ini adalah data yang bersifat kuantitatif. Statistik inferensial, (statistic induktif atau statistic probabilitas), adalah teknik statistik yang digunakan untuk menganalisis data sampel dan hasilnya diberlakukan untuk populasi (Sugiyono dalam Kalnadi 2013). Sesuai dengan hipotesis yang telah dirumuskan, maka dalam penelitian ini analisis data statistik inferensial diukur dengan menggunakan software SmartPLS (Partial Least Square) mulai dari pengukuran model (outer model), struktur model (inner model) dan pengujian hipotesis. PLS (Partial Least Square) menggunakan metoda principle component analiysis dalam model pengukuran, yaitu blok ekstraksi varian untuk melihat hubungan indikator dengan konstruk latennya dengan menghitung total varian yang terdiri atas varian umum (common variance), varian spesifik (specific variance), dan 


\section{- 1 - P Jurnal Audit \& Perpajakan}

Volume : 1 | Nomor 1 | November 2021 | E-ISSN : 2809-1809. | DOI: 10.47709/jap.v1n1.1176

varian error (error variance). Sehingga total varian menjadi tinggi. Model pengembangan menggunakan analisis jalur (path analisis) sebagai berikut :

$$
\mathbf{Y}_{1}=\mathbf{a}+\mathbf{b}_{1} \mathbf{X}_{1}+\mathbf{b}_{2} \mathbf{X}_{2}+\mathbf{e}_{1}
$$

Model struktural (inner model) merupakan model struktural untuk memprediksi hubungan kausalitas antar variabel laten. Melalui proses bootstrapping, parameter uji T-statistic diperoleh untuk memprediksi adanya hubungan kausalitas. Model struktural (inner model) dievaluasi dengan melihat persentase varian yang dijelaskan oleh nilai $R 2$ untuk variabel dependen dengan menggunakan ukuran Stone-Geisser $Q$-square test (Ghozali, 2016) dan juga melihat besarnya koefisien jalur strukturalnya

\section{Hasil}

Karakteristik Responden

Tabel 1 Karakteristik Responden Berdasarkan Jenis Kelamin

\begin{tabular}{|c|l|c|c|}
\hline \multirow{2}{*}{ No } & \multicolumn{1}{|c|}{$\begin{array}{c}\text { Jenis } \\
\text { Kelamin }\end{array}$} & Jumlah & \multirow{2}{*}{ (\%) } \\
\cline { 3 - 3 } & \multicolumn{1}{|c|}{ (Orang) } & \\
\hline 1 & Perempuan & 76 & 76,00 \\
\hline 2 & Laki-laki & 24 & 24,00 \\
\hline & Jumlah & 100 & 100 \\
\hline
\end{tabular}

Sumber: Hasil Penelitian, 2021 (data diolah)

Tabel 2 Karakteristik Responden Berdasarkan Usia

\begin{tabular}{|c|c|c|c|}
\hline No & $\begin{array}{c}\text { Usia } \\
\text { (Tahun) }\end{array}$ & $\begin{array}{c}\text { Jumlah } \\
\text { (Orang) }\end{array}$ & \% \\
\hline 1 & $<25$ & 4 & 4,00 \\
\hline 2 & $25-30$ & 8 & 8,00 \\
\hline 3 & $31-35$ & 11 & 11,00 \\
\hline 4 & $36-40$ & 30 & 30,00 \\
\hline 5 & $41-45$ & 38 & 38,00 \\
\hline 6 & $46-55$ & 9 & 9,00 \\
\hline & Total & 100 & 100 \\
\hline
\end{tabular}

Sumber: Hasil Penelitian, 2021 (data diolah)

Karakteristik Responden Berdasarkan Tingkat Pendidikan

Tabel 3 Karakteristik Responden Berdasarkan Tingkat Pendidikan

\begin{tabular}{|c|l|c|c|}
\hline \multirow{2}{*}{ No } & \multicolumn{1}{|c|}{$\begin{array}{c}\text { Tingkat } \\
\text { Pendidikan }\end{array}$} & Jumlah & \multirow{2}{*}{$(\boldsymbol{\%})$} \\
\cline { 3 - 3 } & \multicolumn{1}{|c|}{ (Orang) } & \\
\hline 1 & SLTA & 36 & 36,00 \\
\hline 2 & DIII & 25 & 25,00 \\
\hline 3 & Strata 1 (S1) & 37 & 37,00 \\
\hline 4 & Strata 2 (S2) & 2 & 2,00 \\
\hline & Jumlah & $\mathbf{1 0 0}$ & $\mathbf{1 0 0}$ \\
\hline
\end{tabular}

Sumber: Hasil Penelitian, 2021 (data diolah) 


\section{J.A.P}

Volume : 1 | Nomor 1 | November 2021 | E-ISSN : 2809-1809. | DOI: 10.47709/jap.v1n1.1176

Tabel 4 Karakteristik Responden Berdasarkan Masa Kerja

\begin{tabular}{|c|l|c|c|}
\hline No & \multicolumn{1}{|c|}{$\begin{array}{c}\text { MasaKerja } \\
\text { (Tahun) }\end{array}$} & $\begin{array}{c}\text { Jumlah } \\
\text { (Orang) }\end{array}$ & $\mathbf{( \% )}$ \\
\hline 1 & $0-5$ & 11 & 11,00 \\
\hline 2 & $6-11$ & 21 & 21,00 \\
\hline 3 & $12-17$ & 56 & 56,00 \\
\hline 4 & $>17$ & 12 & 12,00 \\
\hline & Jumlah & $\mathbf{1 0 0}$ & $\mathbf{1 0 0}$ \\
\hline
\end{tabular}

Sumber: Hasil Penelitian, 2021 (data diolah)

\section{Analisis Statistik Deskriptif}

Tabel 5 Descriptive Statistics

\begin{tabular}{|l|r|r|r|r|r|}
\hline & N & Minimum & Maximum & Mean & Std. Deviation \\
\hline Pengetahuan Pajak (X1) & 100 & 10 & 30 & 21.23 & 4.199 \\
Sanksi Pajak (X2) & 100 & 12 & 35 & 25.25 & 4.582 \\
Kepatuhan Pajak (Y) & 100 & 17 & 49 & 33.91 & 6.627 \\
Valid N (listwise) & 100 & & & & \\
\hline
\end{tabular}

Sumber: Hasil Penelitian, 2021 (data diolah)

Tabel 6 Penjelasan Responden terhadap Pengetahuan Pajak $\left(\mathbf{X}_{1}\right)$

\begin{tabular}{|c|c|c|c|c|c|c|c|c|c|c|}
\hline \multirow[b]{2}{*}{ No } & \multirow[b]{2}{*}{ Uraian } & \multicolumn{9}{|c|}{ JawabanResponden } \\
\hline & & STS & $\mathbf{T S}$ & $\mathbf{K S}$ & $\mathbf{S}$ & SS & $\begin{array}{c}\mathbf{M} \\
\mathbf{i} \\
\mathbf{n}\end{array}$ & $\begin{array}{c}\mathbf{M} \\
\mathbf{a} \\
\mathbf{x}\end{array}$ & $\begin{array}{l}\text { Rata- } \\
\text { rata }\end{array}$ & $\begin{array}{c}K \\
\text { e } \\
\text { t }\end{array}$ \\
\hline 1 & $\begin{array}{l}\text { Pengetahuan mengenai Ketentuan } \\
\text { Umum tentang pajak }\end{array}$ & 1 & 20 & 27 & 30 & 22 & 1 & 5 & 3,52 & $\begin{array}{c}\text { Sangat } \\
\text { Baik }\end{array}$ \\
\hline 2 & $\begin{array}{l}\begin{array}{l}\text { Pengetahuan mengenai } \\
\text { Perpajakan }\end{array} \\
\end{array}$ & 0 & 18 & 20 & 49 & 13 & 2 & 5 & 3,57 & $\begin{array}{c}\text { Sangat } \\
\text { Baik }\end{array}$ \\
\hline 3 & $\begin{array}{l}\text { Pengetahuan mengenai sistem } \\
\text { perpajakan di Indonesia }\end{array}$ & 0 & 17 & 24 & 41 & 18 & 2 & 5 & 3,60 & $\begin{array}{c}\text { Sangat } \\
\text { Baik }\end{array}$ \\
\hline 4 & $\begin{array}{l}\text { Pengentahuan tentang sistem } \\
\text { menyelesaikan perpajakan di Indonesia }\end{array}$ & 2 & 13 & 25 & 44 & 16 & 1 & 5 & 3,59 & $\begin{array}{c}\text { Sangat } \\
\text { Baik }\end{array}$ \\
\hline 5 & $\begin{array}{l}\text { Pengetahuan mengenai fungsi } \\
\text { perpajakan. }\end{array}$ & 1 & 13 & 37 & 33 & 16 & 1 & 5 & 3,50 & $\begin{array}{c}\text { Sangat } \\
\text { Baik }\end{array}$ \\
\hline 6 & $\begin{array}{l}\text { Pengetahuan mengenai manfaat yang } \\
\text { diperoleh setelah mengikuti wajib pajak }\end{array}$ & 2 & 16 & 32 & 36 & 14 & 1 & 5 & 3,44 & $\begin{array}{c}\text { Sangat } \\
\text { Baik }\end{array}$ \\
\hline
\end{tabular}

Sumber: Hasil Penelitian, 2021 (data diolah) 
Tabel 7 Penjelasan Responden terhadap Sanksi Pajak $\left(\mathbf{X}_{2}\right)$

\begin{tabular}{|c|c|c|c|c|c|c|c|c|c|c|}
\hline \multirow[b]{2}{*}{ No } & \multirow[b]{2}{*}{ Uraian } & \multicolumn{9}{|c|}{ JawabanResponden } \\
\hline & & STS & TS & $\mathbf{K S}$ & $\mathbf{S}$ & SS & $\begin{array}{c}\text { M } \\
\mathbf{i} \\
\mathbf{n}\end{array}$ & $\begin{array}{c}\mathbf{M} \\
\mathbf{a} \\
\mathbf{x}\end{array}$ & $\begin{array}{l}\text { Rata- } \\
\text { rata }\end{array}$ & $\begin{array}{l}\mathbf{K} \\
\mathbf{e} \\
\mathbf{t}\end{array}$ \\
\hline 1 & $\begin{array}{llll}\begin{array}{l}\text { Keterlambatan } \\
\text { dikenai sanksi }\end{array} & \text { melaporkan } & \text { pajak harus } \\
\end{array}$ & 1 & 11 & 36 & 32 & 20 & 1 & 5 & 3,59 & $\begin{array}{c}\text { Sangat } \\
\text { Baik }\end{array}$ \\
\hline 2 & $\begin{array}{l}\text { Keterlambatan membayarkan pajak harus } \\
\text { dikenai sanksi }\end{array}$ & 2 & 15 & 25 & 34 & 24 & 1 & 5 & 3,63 & $\begin{array}{c}\text { Sangat } \\
\text { Baik }\end{array}$ \\
\hline 3 & $\begin{array}{l}\text { Tingkat penerapan sanksi dari yang ringan } \\
\text { sampai berat }\end{array}$ & 7 & 21 & 29 & 27 & 16 & 1 & 5 & 3,24 & $\begin{array}{c}\text { Sangat } \\
\text { Baik }\end{array}$ \\
\hline 4 & $\begin{array}{l}\text { Tingkat penerapan sanksi dimulai dari adanya } \\
\text { teguran buat wajib pajak }\end{array}$ & 2 & 14 & 26 & 33 & 25 & 1 & 5 & 3,65 & $\begin{array}{c}\text { Sangat } \\
\text { Baik }\end{array}$ \\
\hline 5 & $\begin{array}{l}\text { Sanksi digunakan untuk meningkatkan } \\
\text { kepatuhan Wajib Pajak }\end{array}$ & 2 & 9 & 21 & 42 & 26 & 1 & 5 & 3,81 & $\begin{array}{c}\text { Sangat } \\
\text { Baik }\end{array}$ \\
\hline 6 & $\begin{array}{l}\text { Sanksi yang diberikan untuk mengingatkan } \\
\text { wajib pajak patuh terhadap peraturan yang } \\
\text { berlaku }\end{array}$ & 6 & 17 & 28 & 25 & 24 & 1 & 5 & 3,44 & $\begin{array}{c}\text { Sangat } \\
\text { Baik }\end{array}$ \\
\hline 7 & $\begin{array}{l}\text { Penghapusan sanksi meningkatkan kepatuhan } \\
\text { Wajib Pajak. }\end{array}$ & 1 & 14 & 24 & 33 & 28 & 1 & 5 & 3,73 & $\begin{array}{c}\text { Sangat } \\
\text { Baik }\end{array}$ \\
\hline 8 & $\begin{array}{l}\text { Pengapusan sanksi tidak membuat wajib } \\
\text { pajak jadi tidak patuh terhadap kewajibannya }\end{array}$ & 2 & 15 & 27 & 38 & 18 & 1 & 5 & 3,55 & $\begin{array}{c}\text { Sangat } \\
\text { Baik }\end{array}$ \\
\hline
\end{tabular}

Sumber: Hasil Penelitian, 2021 (data diolah)

Tabel 8 Penjelasan Responden terhadap Kepatuhan Pajak (Y)

\begin{tabular}{|c|c|c|c|c|c|c|c|c|c|c|}
\hline \multirow[b]{2}{*}{ No } & \multirow[b]{2}{*}{ Uraian } & \multicolumn{9}{|c|}{ JawabanResponden } \\
\hline & & STS & TS & KS & $\mathbf{S}$ & SS & $\begin{array}{c}\mathbf{M} \\
\mathbf{i} \\
\mathbf{n}\end{array}$ & $\begin{array}{c}\mathbf{M} \\
\mathbf{a} \\
\mathbf{x}\end{array}$ & $\begin{array}{c}\text { Rata- } \\
\text { rata }\end{array}$ & $\begin{array}{l}\mathbf{K} \\
\mathbf{e} \\
\mathbf{t}\end{array}$ \\
\hline 1 & $\begin{array}{l}\text { Tepat waktu dalam penyampaian SPT untuk } \\
\text { semua jenis pajak dalam satu tahun }\end{array}$ & 2 & 16 & 28 & 35 & 19 & 1 & 5 & 3,53 & $\begin{array}{c}\text { Sangat } \\
\text { Baik }\end{array}$ \\
\hline 2 & $\begin{array}{l}\text { Tepat waktu dalam penyampaian SPT cukup } \\
\text { mempermudah wajib pajak dalam } \\
\text { mendapatkan pelayanan }\end{array}$ & 6 & 21 & 24 & 36 & 13 & 1 & 5 & 3,29 & $\begin{array}{c}\text { Sangat } \\
\text { Baik }\end{array}$ \\
\hline 3 & $\begin{array}{l}\text { Tidak mempunyai tunggakan untuk semua jenis } \\
\text { pajak. }\end{array}$ & 2 & 15 & 29 & 36 & 18 & 1 & 5 & 3,53 & $\begin{array}{c}\text { Sangat } \\
\text { Baik }\end{array}$ \\
\hline 4 & $\begin{array}{l}\text { Kebiasaan wajib pajak dalam melaporkan } \\
\text { pajaknya berdampak tidak mempuanyai } \\
\text { tunggakan }\end{array}$ & 3 & 19 & 31 & 34 & 13 & 1 & 5 & 3,35 & $\begin{array}{c}\text { Sangat } \\
\text { Baik }\end{array}$ \\
\hline 5 & $\begin{array}{l}\text { Tidak pernah dijatuhi hukuman karena } \\
\text { melakukan tindak pidana dalam bidang pajak } \\
\text { selama } 10-15 \text { tahun }\end{array}$ & 3 & 19 & 26 & 34 & 18 & 1 & 5 & 3,45 & $\begin{array}{c}\text { Sangat } \\
\text { Baik }\end{array}$ \\
\hline 6 & $\begin{array}{l}\text { Tidak pernah menggelapkan pajak kepada } \\
\text { pihak yang berwenang selama } 10-15 \text { tahun }\end{array}$ & 2 & 19 & 32 & 31 & 16 & 1 & 5 & 3,40 & $\begin{array}{c}\text { Sangat } \\
\text { Baik }\end{array}$ \\
\hline 7 & $\begin{array}{l}\text { Dalam dua tahun terakhir menyelenggarakan } \\
\text { pembukuan yang memadai }\end{array}$ & 1 & 18 & 31 & 30 & 20 & 1 & 5 & 3,50 & $\begin{array}{c}\text { Sangat } \\
\text { Baik }\end{array}$ \\
\hline 8 & $\begin{array}{l}\text { Telah dilakukan pemeriksaan. Koreksi pada } \\
\text { pemeriksaan yang terakhir untuk jenis pajak } \\
\text { terutang paling banyak } 5 \% \text {. }\end{array}$ & 3 & 23 & 28 & 34 & 12 & 1 & 5 & 3,29 & $\begin{array}{c}\text { Sangat } \\
\text { Baik }\end{array}$ \\
\hline
\end{tabular}




\section{- 1 - Jurnal Audit \& Perpajakan}

Volume : 1 | Nomor 1 | November 2021 | E-ISSN : 2809-1809. | DOI: 10.47709/jap.v1n1.1176

\begin{tabular}{|c|l|c|c|c|c|c|c|c|c|c|}
\hline \hline 9 & $\begin{array}{l}\text { Wajib Pajak yang laporan keuangannya dalam } \\
\text { dua tahun terakhir diaudit dengan pendapat } \\
\text { wajar tanpa pengecualian }\end{array}$ & 6 & 20 & 31 & 27 & 16 & 1 & 5 & 3,27 & $\begin{array}{c}\text { Sangat } \\
\text { Baik }\end{array}$ \\
\hline 10 & $\begin{array}{l}\text { Wajib Pajak wajar dengan pengecualian tidak } \\
\text { mempengaruhi laba rugi fiskal. }\end{array}$ & 5 & 24 & 25 & 28 & 18 & 1 & 5 & 3,30 & $\begin{array}{c}\text { Sangat } \\
\text { Baik }\end{array}$ \\
\hline
\end{tabular}

Sumber: Hasil Penelitian, 2021 (data diolah)

\section{Metode Partial Least Square (PLS)}

Dalam penelitian ini metode yang digunakan adalah Partial Least Square (PLS), alasan menggunakan metode ini yaitu untuk menjelaskan ada tidaknya hubungan antara variabel laten, kemudian untuk menguji pemodelan yang berbasis teori berdasarkan pendapat parah ahli maupun hasil penelitian terdahulu yang indikator dari variabel tersebut saling berhubungan dalam menjelaskan kondisi yang terjadi saat ini. Berdasarkan hasil teori maupun penelitian terdahulu maka variabel yang akan diuji terdiri dari variabel independen yaitu: Pengetahuan Pajak $\left(\mathrm{X}_{1}\right)$, Sanksi Pajak $\left(\mathrm{X}_{2}\right)$. Setelah ditentukannya masing-masing variabel yang diperkuat dari teori dan penelitian terdahulu, maka peneliti telah mempersiapkan data-data yang berasal dari pengamatan di lapangan dan pengumpulan kuisioner dan mempersiapkan Model Partial Least Square (PLS).

\section{Skema Model Partial Least Square (PLS)}

Pada penelitian ini, pengujian hipotesis menggunakan teknik analisis Partial Least Square (PLS) dengan program SmartPLS, berikut ini adalah sekema model program PLS yang diujikan:

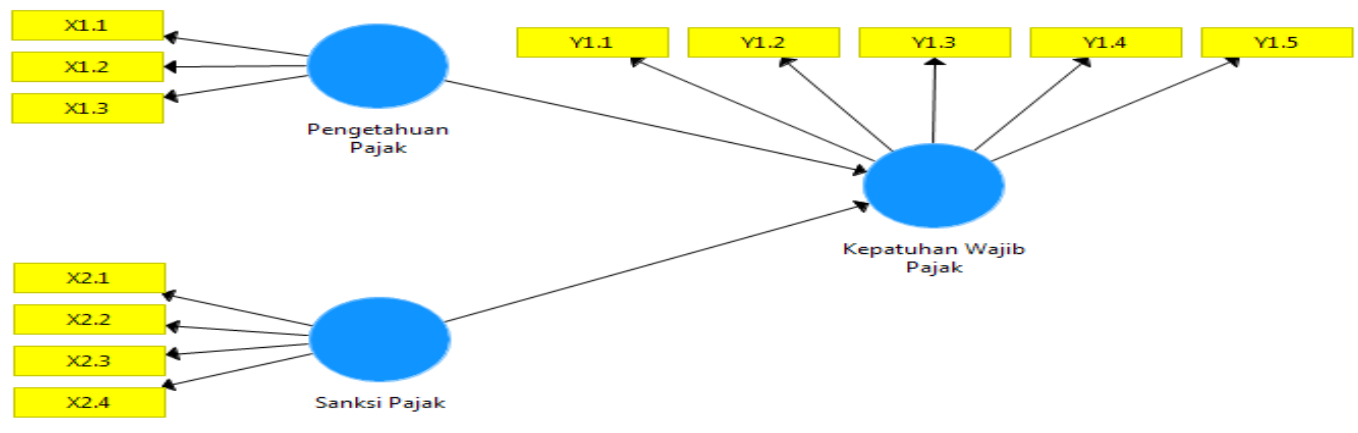

\section{Gambar 1 Outer Model PLS}

Pada Gambar 1 ditampilkan Outer Model PLS yang dibangun dari kerangka konseptual. Gambar ini menjelaskan hubungan antara masing-masing variabel yang bersumber dari berbagai teori maupun penelitian terdahulu, Untuk masing-masing variabel yang diuji dilengkapi dengan indikator-indikator yang dibangun dari hubungan antara teori-teori. Hasil analisis dengan menggunakan Partial Least Square (PLS) dapat dilihat pada uraian berikutnya. 


\section{- 1 - P Jurnal Audit \& Perpajakan}

Volume : 1 | Nomor 1 | November 2021 | E-ISSN : 2809-1809. | DOI: 10.47709/jap.v1n1.1176

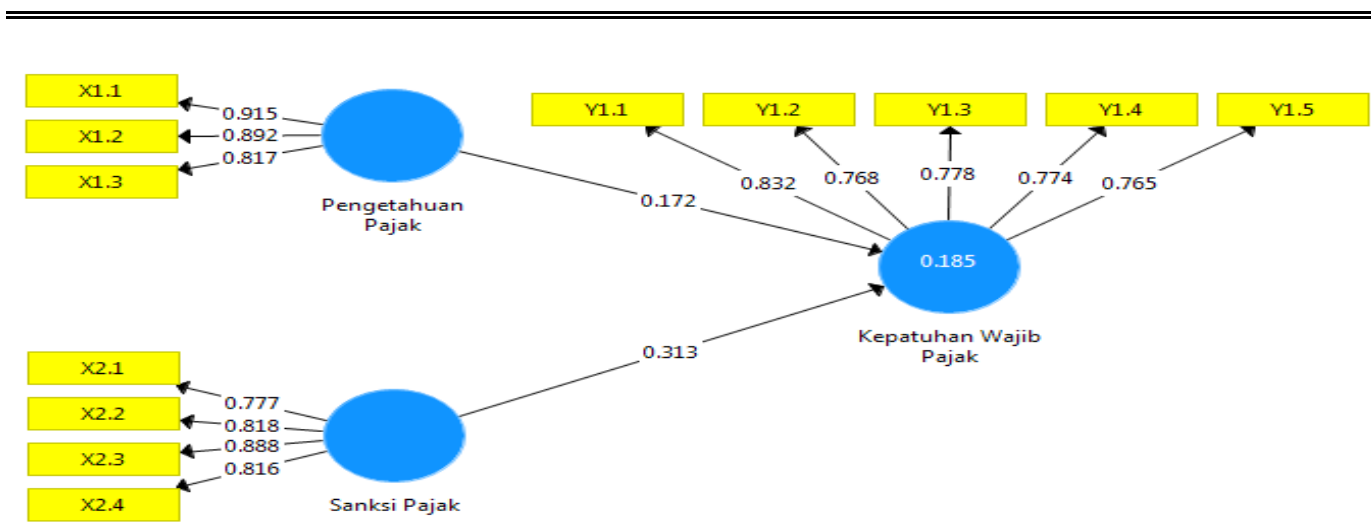

Gambar 2 Inner Model PLS

\section{Evaluasi Model}

\section{Convergen Validity}

Untuk menguji convergent validity digunakan outer loading atau loading factor. Suatu indikator dinyakatakan memenuhi convergent validity dalam kategori baik apabila nilai outer loading $>0,70$. Berikut ini adalah outer loading dari masing-masing indikator pada variabel penelitian :

\section{Tabel 9 Outer loading}

\begin{tabular}{|c|c|c|}
\hline Variabel & Indikator & Outer Loading \\
\hline \multirow{3}{*}{ Pengetahuan Pajak $\left(\mathrm{X}_{1}\right)$} & $\mathrm{X} 1.1$ & 0,915 \\
\cline { 2 - 3 } & $\mathrm{X} 1.2$ & 0,892 \\
\cline { 2 - 3 } & $\mathrm{X} 1.3$ & 0.817 \\
\hline \multirow{4}{*}{ Sanksi Pajak $\left(\mathrm{X}_{2}\right)$} & $\mathrm{X} \mathrm{2.1}$ & 0,777 \\
\cline { 2 - 3 } & $\mathrm{X} \mathrm{2.2}$ & 0,818 \\
\cline { 2 - 3 } & $\mathrm{X} \mathrm{2.3}$ & 0,888 \\
\cline { 2 - 3 } & $\mathrm{X} \mathrm{2.4}$ & 0,816 \\
\hline \multirow{4}{*}{$\begin{array}{c}\text { Kepatuhan Pajak } \\
\text { (Y) }\end{array}$} & $\mathrm{Y} 1$ & 0,832 \\
\cline { 2 - 3 } & $\mathrm{Y} 2$ & 0,768 \\
\cline { 2 - 3 } & $\mathrm{Y3}$ & 0,778 \\
\cline { 2 - 3 } & $\mathrm{Y} 4$ & 0,774 \\
\cline { 2 - 3 } & $\mathrm{Y} 5$ & 0,765 \\
\hline
\end{tabular}

Sumber: Hasil Penelitian, 2021 (data diolah)

Berdasarkan Tabel 9, diketahui bahwa masing-masing indikator variabel penelitian memiliki nilai outer loading $>0,7$. Hasil outer loadingmenunjukkan tidak ada indikator variabel yang nilai outer loadingnya dibawah 0,6 sehingga semua indikator dinyatakan layak atau valid untuk digunakan penelitian dan dapat digunakan untuk analisis lebih lanjut.

\section{Dicriminat Validitiy}

Pada bagian ini akan diuraikan hasil uji discriminant validity. Uji discriminant validitiy menggunakan nilai cross loading. Suatu indikator dinyatakan memenuhi discriminant validity apabila nilai cross loading indikator pada variabelnya adalah yang terbesar dibandingkan pada variabel lainnnya. Untuk mengamati nilai cross loading, discriminant validity juga dapat diketahui melalui metode lainnya yaitu dengan melihat average variant extracted (AVE) untuk masing-masing indikator dipersyaratkan nilainya harus >0,5 untuk model yang baik, Nilai average variant extracted (AVE) sebagai berikut: 
\.1. D Jurnal Audit \& Perpajakan

Volume : 1 | Nomor 1 | November 2021 | E-ISSN : 2809-1809. | DOI: 10.47709/jap.v1n1.1176

Tabel 10 Average Variant Extracted (AVE)

\begin{tabular}{|c|c|}
\hline Variabel & AVE \\
\hline Pengetahuan Pajak $\left(\mathrm{X}_{1}\right)$ & 0,615 \\
\hline Sanksi Pajak $\left(\mathrm{X}_{2}\right)$ & 0,767 \\
\hline Kepatuhan Pajak $(\mathrm{Y})$ & 0,682 \\
\hline
\end{tabular}

Sumber: Hasil Penelitian, 2021 (data diolah)

Berdasarkan Tabel 10, diketahui bahwa nilai AVE variabel Pengetahuan Pajak $\left(\mathrm{X}_{1}\right)$, Sanksi Pajak $\left(\mathrm{X}_{2}\right)$ dan Kepatuhan Pajak $(\mathrm{Y})>0,5$. Dengan demikian dapat dinyatakan bahwa setiap variabel telah memiliki discriminant validity yang baik.

\section{Composite Reliablity}

Composite Reliablitymerupakan bagian yang digunakan untuk menguji nilai reliabilitas indikatorindikator pada suatu variabel, Suatu variabel dapat dinyatakan memnenuhi composite reliability apabila memiliki nilai composite reliability dari masing-masing variabel yang digunakan dalam penelitian ini:

Tabel 11 Composite Reliability

\begin{tabular}{|c|c|}
\hline Variabel & Composite Reliability \\
\hline Pengetahuan Pajak $\left(\mathrm{X}_{1}\right)$ & 0,888 \\
\hline Sanksi Pajak $\left(\mathrm{X}_{2}\right)$ & 0,908 \\
\hline Kepatuhan Pajak $(\mathrm{Y})$ & 0,895 \\
\hline
\end{tabular}

Sumber: Hasil Penelitian, 2021 (data diolah)

Berdasarkan Tabel 11 dapat diketahui bahwa nilai composite reliability variabel Pengetahuan Pajak $\left(\mathrm{X}_{1}\right)$, Sanksi Pajak $\left(\mathrm{X}_{2}\right)$ dan Kepatuhan Pajak > 0,60. Hasil ini menunjukkan bahwa masing-masing variabel telah memenuhi composite reliability sehingga dapat disimpulkan bahwa keseluruhan variabel memiliki tingkat reliabilitas yang tinggi.

\section{Cronbach Alpha}

Uji reliabilitas dengan composite reliability diatas dapat diperkuat dengan menggunakan nilai cronbach alpha. Suatu variabel dapat dinyatakan reliabel atau memenuhi cronbach alpha apabila memiliki nilai cronbah alpha $>0,7$, berikut ini adalah nilai cronbach alpha dari masing-masing variabel:

Tabel 12 Cronbach Alpha

\begin{tabular}{|c|c|}
\hline Variabel & Cronbach Alpha \\
\hline Pengetahuan Pajak $\left(\mathrm{X}_{1}\right)$ & 0,844 \\
\hline Sanksi Pajak $\left(\mathrm{X}_{2}\right)$ & 0,853 \\
\hline Kepatuhan Pajak $(\mathrm{Y})$ & 0,848 \\
\hline
\end{tabular}

Sumber: Hasil Penelitian, 2021 (data diolah)

Berdasarkan Tabel 12 dapat diketahui bahwa nilai cronbach alpha dari masing variabel Pengetahuan Pajak $\left(\mathrm{X}_{1}\right)$, Sanksi Pajak $\left(\mathrm{X}_{2}\right)$ dan Kepatuhan Pajak $(\mathrm{Y})>0,70$. Dengan demikian hasil ini dapat menunjukkan masing-masing variabel penelitian telah memenuhi persyaratan nilai cronbach alpha, sehingga dapat disimpulkan bahwa keseluruhan variabel memiliki tingkat reliabilitas yang tinggi.

\section{Evaluasi Inner Model}

Pada penelitian ini akan dijelaskan mengenai hasil uji path coefficient, uji goodnessof fit dan uji hipotesis 
\. • P Jurnal Audit \& Perpajakan

Volume : 1 | Nomor 1 | November 2021 | E-ISSN : 2809-1809. | DOI: 10.47709/jap.v1n1.1176

\section{Uji Path Coefficient}

Evaluasi path coefficient digunakan untuk menunjukkan seberapa kuat efek atau pengaruh variabel independen kepada variabel dependen. Sedangkan coefficient determination (R-Square) digunakan untuk mengukur seberapa banyak variabel endogen diengaruhi oleh variabel lainnya. Menurut Ghozali (2016) hasil $R$-Square sebesar 0,67 ke atas untuk variabel laten endogen dalam model struktural mengindikasikan pengaruh variabel eksogen (yang mempengaruhi) terhadap variabel endogen (yang dipengaruhi) termasuk dalam kategori baik. Sedangkan jika hasilnya sebesar 0,33-0,67 maka termasuk dalam kategori sedang, dan jika hasilnya sebesar 0,19-0,33 maka termasuk dalam kategori lemah.

Berdasarkan uraian hasil tersebut,menunjukkan bahwa keseluruhan variabel dalam model ini memilikii path coefficient dengan angka positif. Hal ini menunjukkan bahwa jika semakin besar nilai path coefficient pada satu variabel independen terhadap variabel dependen, maka semakin kuat pula pengaruh antar variabel independen terhadap variabel dependen tersebut.

\section{Uji kebaikan Model (Goodness Of Fit)}

Berdasarkan pengolahan data yang telah dilakukan dengan menggunakan program smartPLS, diperoleh nilai $R$-Square Ajusted sebagai berikut:

Tabel 13 Nilai $R$-Square

\begin{tabular}{|c|c|}
\hline Variabel & $\boldsymbol{R}$ Square Adjusted \\
\hline Kepatuhan Pajak (Y) & 0.168 \\
\hline
\end{tabular}

Sumber: Hasil Penelitian, 2021 (data diolah)

Berdasarkan Tabel 13 dapat diketahui bahwa nilai $R$-Square Adjusted untuk Pengetahuan Pajak $\left(\mathrm{X}_{1}\right)$ dan Sanksi Pajak $\left(\mathrm{X}_{2}\right)$ sebesar 16,8\%. nilai tesebut menjelaskan bahwa Kepatuhan Pajak (Y) dapat dijelaskan oleh Pengetahuan Pajak $\left(\mathrm{X}_{1}\right)$, Sanksi Pajak $\left(\mathrm{X}_{2}\right)$. Hasil penelitian menunjukkan bahwa hubungan antara Pengetahuan Pajak $\left(\mathrm{X}_{1}\right)$ dan Sanksi Pajak $\left(\mathrm{X}_{2}\right)$ terhadap Kepatuhan Pajak $(\mathrm{Y})$ tergolong masih rendah karena nilai $R$-Square Adjusted yang diperoleh dibawah $50 \%$.

Penilaian gooodness of fit diketahui dari nilai $q$-square. Nilai $q$-square memiliki arti yang sama dengan coefficient determination ( $R$-square) pada analisis regresi, dimana semakin tinggi q-square, maka model dapat dikatakan semakin baik atau semakin fit dengan data.

\section{Uji Hipotesis}

Berdasarkan olah data yang telah dillakukan, hasilnya dapat digunakan untuk menjawab hipotesis pada penelitian ini. Uji hipotesis pada penelitian ini dapat dilakukan dengan melihat nilai T-statistic dan nilai $\mathrm{P}$-values. Hipotesis penelitian ini dapat dinyatakan diterima apabila nilai P-values $<0,05$. Hasil uji hipotesis yang diperoleh dalam penelitian ini melalui inner mode.

\section{Uji Hipotesis}

\begin{tabular}{|c|l|c|c|c|c|}
\hline Hipotesis & \multicolumn{1}{|c|}{ Pengaruh Variabel } & $\begin{array}{c}\text { Sample } \\
\text { Mean (M) }\end{array}$ & $\begin{array}{c}\text { T- } \\
\text { Statistics }\end{array}$ & $\begin{array}{c}\text { P- } \\
\text { value }\end{array}$ & Hasil \\
\hline H1 & $\begin{array}{l}\text { Pengetahuan Pajak }\left(\mathrm{X}_{1}\right)=> \\
\text { Kepatuhan Pajak }(\mathrm{Y})\end{array}$ & 0,194 & 1,639 & 0,124 & Ditolak \\
\hline H2 & $\begin{array}{l}\text { Sanksi Pajak }\left(\mathrm{X}_{2}\right)=> \\
\text { Kepatuhan Pajak }(\mathrm{Y})\end{array}$ & 0,321 & 2,759 & 0,007 & Diterima \\
\hline
\end{tabular}

Sumber: Hasil Penelitian, 2021 (data diolah)

Berdasarkan pada Tabel 14 maka diperoleh hasil uji parsial sebagai berikut:

1. Nilai $t_{\text {hitung }}$ untuk Pengetahuan Pajak $\left(\mathrm{X}_{1}\right)$ sebesar 1,639 lebih kecil dengan membandingkan derajat bebas $(\mathrm{DF}=\mathrm{n}-\mathrm{k}=100-2=98)$ maka diperoleh nilai $\mathrm{t}_{\text {tabel }}(1,66)$, atau nilai sig $\mathrm{t}$ untuk Pengetahuan Pajak 
\. • P Jurnal Audit \& Perpajakan

Volume : 1 | Nomor 1 | November 2021 | E-ISSN : 2809-1809. | DOI: 10.47709/jap.v1n1.1176

$\left(\mathrm{X}_{1}\right)$ sebesar 0,124 lebih besar dari alpha $(0,05)$. Berdasarkan hasil yang diperoleh maka menolak $\mathrm{H}_{0}$ dan menerima $\mathrm{H}_{1}$ untuk Pengetahuan Pajak $\left(\mathrm{X}_{1}\right)$. Dengan demikian, secara parsial Pengetahuan Pajak $\left(\mathrm{X}_{1}\right)$ tidak berpengaruh positif dan tidak signifikan terhadap Kepatuhan Pajak (Y), artinya. Arah pengaruh negatif, menunjukan bahwa variaebel Pengetahuan Pajak $\left(\mathrm{X}_{1}\right)$ tidak berpengaruh kepada Kepatuhan Pajak (Y).

2. Nilai $t_{\text {hitung }}$ untuk Sanksi Pajak $\left(\mathrm{X}_{2}\right)$ sebesar 2,759 lebih besar dengan membandingkan derajat bebas $(\mathrm{DF}=\mathrm{n}-\mathrm{k}=100-2=98)$ maka diperoleh nilai $\mathrm{t}_{\text {tabel }}(1,66)$, atau nilai sig t untuk Sanksi Pajak $\left(\mathrm{X}_{2}\right)(0,007)$ lebih kecil dari alpha $(0,05)$. Berdasarkan hasil yang diperoleh maka menolak $\mathrm{H}_{0}$ dan menerima $\mathrm{H}_{1}$. Dengan demikian secara parsial Sanksi Pajak $\left(\mathrm{X}_{2}\right)$ berpengaruh positif dan signifikan terhadap Kepatuhan Pajak (Y), artinya Sanksi Pajak $\left(\mathrm{X}_{2}\right)$ memberikan dampak yang nyata dalam meningkatkan Kepatuhan Pajak (Y).

\section{Pembahasan}

\section{Pengaruh Pengetahuan Pajak $\left(X_{1}\right)$ Terhadap Kepatuhan Pajak (Y) Pada UMKM Yang ada Di Kota Medan}

Hasil penelitian diperoleh Nilai thitung untuk Pengetahuan Pajak $\left(\mathrm{X}_{1}\right)$ lebih kecil dan nilai sig t untuk Pengetahuan Pajak $\left(\mathrm{X}_{1}\right)$ sebesar 0,124 lebih besar dari alpha $(0,05)$. Berdasarkan hasil yang diperoleh maka menerima $\mathrm{H}_{0}$ dan menolak $\mathrm{H}_{1}$ untuk Pengetahuan Pajak $\left(\mathrm{X}_{1}\right)$. Dengan demikian, secara parsial Pengetahuan Pajak $\left(\mathrm{X}_{1}\right)$ tidak berpengaruh positif dan tidak signifikan terhadap Kepatuhan Pajak (Y), menunjukkan Pengetahuan Pajak $\left(\mathrm{X}_{1}\right)$ tidak memberikan dampak positif dalam meningkatkan Kepatuhan Pajak (Y).

Pengaruh Sanksi Pajak $\left(\mathrm{X}_{2}\right.$ ) Terhadap Kepatuhan Pajak (Y) Pada UMKM Yang ada Di Kota Medan Hasil penelitian diperoleh nilai $\mathrm{t}_{\text {hitung }}$ untuk Sanksi Pajak $\left(\mathrm{X}_{2}\right)$ sebesar 2,759 lebih besar demgan nilai sig $\mathrm{t}$ untuk Sanksi Pajak $\left(\mathrm{X}_{2}\right)$ sebesar 0,007 lebih kecil dari alpha $(0,05)$. Berdasarkan hasil yang diperoleh maka menolak $\mathrm{H}_{0}$ dan menerima $\mathrm{H}_{1}$. Dengan demikian secara parsial Sanksi Pajak $\left(\mathrm{X}_{2}\right)$ berpengaruh positif dan signifikan terhadap Kepatuhan Pajak (Y), artinya Sanksi Pajak $\left(\mathrm{X}_{2}\right)$ memberikan dampak yang nyata dalam meningkatkan Kepatuhan Pajak (Y).

\section{Kesimpulan}

1. Berdasarkan hasil yang diperoleh maka menerima $\mathrm{H}_{0}$ dan menolak, dengan demikian secara parsial Pengetahuan Pajak $\left(\mathrm{X}_{1}\right)$ tidak berpengaruh positif dan tidak signifikan terhadap Kepatuhan Pajak (Y), artinya. Arah pengaruh negatif, menunjukan bahwa variaebel Pengetahuan Pajak $\left(\mathrm{X}_{1}\right)$ tidak berpengaruh kepada Kepatuhan Pajak (Y).

2. Berdasarkan hasil yang diperoleh maka menolak $\mathrm{H}_{0}$ dan menerima $\mathrm{H}_{1}$. Dengan demikian secara parsial Sanksi Pajak $\left(\mathrm{X}_{2}\right)$ berpengaruh positif dan signifikan terhadap Kepatuhan Pajak (Y), artinya Sanksi Pajak $\left(\mathrm{X}_{2}\right)$ memberikan dampak yang nyata dalam meningkatkan Kepatuhan Pajak (Y).

3. Nilai $R$-Square Adjusted untuk Pengetahuan Pajak $\left(\mathrm{X}_{1}\right)$ dan Sanksi Pajak $\left(\mathrm{X}_{2}\right)$ sebesar 16,8\%. nilai tesebut menjelaskan bahwa Kepatuhan Pajak (Y) dapat dijelaskan oleh Pengetahuan Pajak ( $\left.\mathrm{X}_{1}\right)$, Sanksi Pajak $\left(\mathrm{X}_{2}\right)$. Hasil penelitian menunjukkan bahwa hubungan antara Pengetahuan Pajak $\left(\mathrm{X}_{1}\right)$ dan Sanksi Pajak $\left(\mathrm{X}_{2}\right)$ terhadap Kepatuhan Pajak (Y) tergolong masih rendah karena nilai $R$-Square Adjusted yang diperoleh dibawah $50 \%$. 
\. • P Jurnal Audit \& Perpajakan

Volume : 1 | Nomor 1 | November 2021 | E-ISSN : 2809-1809. | DOI: 10.47709/jap.v1n1.1176

\section{Referensi}

Adhimatra, A. A. G. W., \& Noviari, N. (2018). pengaruh kondisi keuangan wajib pajak, kualitas pelayanan fiskus, dan sanksi perpajakan pada kepatuhan wajib pajak Orang Pribadi di Kantor Pelayanan Pajak Pratama Denpasar Timur. E-Jurnal Akuntansi Universitas Udayana, 25(1), 717-744. https://doi.org/10.24843/eja.2018.v25.i01.p27.

Arfah, A., \& Aditama, M. R. (2020). Pengaruh Pengetahuan Perpajakan, Modernisasi Sistem Administrasi Perpajakan, Dan Kesadaran Wajib Pajak Terhadap Kepatuhan Wajib Pajak. Center of Economic Student Journal, 3(3), 301-310. http://journal.student.uny.ac.id/ojs/index.php/profita/article/view/5996

Aqiila, A., Furqon, I. K., \& Ekonomi, F. (2021). Pengaruh sistem e-filing, Sosialisasi Perpajakan, dan Sanksi perpajakan Terhadap Kesadaran dan Kepatuhan Wajib PajakKinerja,Jurnal Ekonomi \& Manajemen, 18(1), 1-7.

Adikara, Arrozi, \& Setianing Rahayu. (2021). Pengaruh Pengenaan Sanksi, Pelayanan Fiskus \& Moralitas Pelayanan Pajak Teradap Kepatuhan Pajak Tahun 2021 (Studi Empiris Terhadap Wajib Pajak Badan Di Kabupaten Bogor Jawa Barat). Comparative: Ekonomi dan Bisnis, 3(1), 93-109.

Ayu, D., \& Hani, U. (2021). Pengaruh Sanksi Pajak Serta Pengetahuan Masyarakat Tentang Pajak Terhadap Kepatuhan Membayar Wajib Pajak. UTILITY: Jurnal Ilmiah Pendidikan dan Ekonomi, 5(1), 10-15.

Chandra, C., \& Sandra, A. (2020). Pengaruh Tarif Pajak, Sanksi Pajak, Dan Kesadaran Wajib Pajak Terhadap Kepatuhan Wajib Pajak Orang Pribadi Usahawan Di Daerah Itc Mangga Dua. Jurnal Online Insan Akuntan, 5(8), 16.

Erica, D. (2021). Pengaruh Sanksi Perpajakan Terhadap Kepatuhan Wajib Pajak Orang Pribadi. Jurnal Ilmiah Manajemen Ubhara, 3(1), 129. https://doi.org/10.31599/jmu.v3i1.857

Hidayat, Taufik \&Putri Esa Afiyanti. (2018). Pengaruh peenerapan e-SPT dan Pengetahuan Perpajakan Terhadap Kepatuhan Wajib Pajak. Jurnal AkuntansiBisnisPelita Bangsa, 3(1), 55-70.

Hazmi, M. Z., Suhendro, \& Dewi, R. R. (2020). Pengaruh pemahaman wajib pajak, kualitas pelayanan dan sanksi perpajakan terhadap kepatuhan wajib pajak pada KPP Pratama Surakarta. Jurnal Akuntansi Universitas Jember, 18(1), 28-40.

Hertati, L. (2021). Pengaruh Tingkat Pengetahuan Perpajakan Dan Modernisasi Sistem Administrasi Perpajakan Terhadap Kepatuhan Wajib Pajak Orang Pribadi. Jurnal Riset Akuntansi Dan Bisnis, 7(Juli), 59-70.

Juwita, \& Wasif, S. K. (2020). Pengaruh Pengetahuan Wajib Pajak Tentang Peraturan Perpajakan , Kesadaran Wajib Pajak, Sanksi Pajak dan Penerapan E-Samsat Terhadap Kepatuhan Wajib Pajak Kendaraan Bermotor ( Studi Kasus Wajib Pajak Kendaraan Bermotor di Kantor Bersama Samsat Jakarta Tim. Sekolah Tinggi Ilmu Ekonomi Indonesia, 1-17.

Kartikasari, Ni Luh Gede Santhi., \& I Ketut Yadnyana. (2020). Pengetahuan Perpajakan, Sanksi Pajak Kesadaran Wajib Pajak dan Kepatuhan WPOP Sektor UMKM. E-Jurnal Akuntansi, 31(4), 925-936. https://doi.org/10.24843/eja.2021.v31.i04.p10.

Mumu, A., Sondakh, J. J., \& Suwetja, I. G. (2020). Pengaruh Pengetahuan Perpajakan, Sanksi Pajak, Dan Kesadaran Wajib Pajak Terhadap Kepatuhan Membayar Pajak Bumi Dan Bangunan Di Kecamatan Sonder Kabupaten Minahasa. Going Concern: Jurnal Riset Akuntansi, 15(2), 175-184. https://doi.org/10.1142/S0217751X20500220

Mulyati, Y., \& Ismanto, J. (2021). Pengaruh Penerapan E-Filing, Pengetahuan Pajak dan Sanksi Pajak Terhadap Kepatuhan Wajib Pajak pada Pegawai Kemendikbud. JABI (Jurnal Akuntansi Berkelanjutan Indonesia), 4(2), 139. https://doi.org/10.32493/jabi.v4i2.y2021.p139-155

Supriatiningsih, S., \& Jamil, F. S. (2021). Pengaruh Kebijakan E-Filing, Sanksi Perpajakan dan Kesadaran Wajib Pajak Terhadap Kepatuhan Wajib Pajak Orang Pribadi. Jurnal Ilmiah Akuntansi Kesatuan, 9(1), 191-200. https://doi.org/10.37641/jiakes.v9i1.560 


\section{- 1 - Jurnal Audit \& Perpajakan}

Volume : 1 | Nomor 1 | November 2021 | E-ISSN : 2809-1809. | DOI: 10.47709/jap.v1n1.1176

Soda, J., Budiarso, J. J. S. N. S., Perpajakan, P. P., Pajak, S., Persepsi, D. A. N., Akuntasi, J., \& Ekonomi, F. (2021). Pengaruh Pengetahuan Perpajakan, Sanksi Pajak Dan Persepsi Keadilan Terhadap Kepatuhan Wajib Pajak Umkm Di Kota Manado. Jurnal EMBA: Jurnal Riset Ekonomi, Manajemen, Bisnis Dan Akuntansi, 9(1), 1115-1126. https://doi.org/10.35794/emba.v9i1.32855.

Tikupadang, W. K., \& Palalangan, C. A. (2020). Pengaruh Kepatuhan Wajib Pajak, Pengetahuan Sistem eFilling, Tax Audit, dan Tax Avoidance terhadap Penerimaan Pajak (Studi Kasus Pada KPP Makassar Utara). Paulus Journal of Accounting (PJA), 1(2), 45-53.

Triandani, \& Apollo, A. (2020). Effect the Understanding of Taxation, Tax Sanctions and Taxpayer Awareness of Taxpayer Compliance (Research on Taxpayers of Individual Entrepreneurs in Tangerang Region). Dinasti International Journal of Digital Business Management, 2(1), 87-93. https://doi.org/10.31933/dijdbm.v2i1.638

Wulandari, R. (2020). Analisis Pemahaman dan Sanksi Perpajakan Terhadap Kepatuhan Wajib Pajak Melalui Preferensi Risiko Sebagai Variabel Moderasi. Journal of Business and Banking, 10(1), 169179. https://doi.org/10.14414/jbb.v10i1.2298.

Yuliansyah, R., Amaliati Setiawan, D., \& Sri Mumpuni, R. (2019). Pengaruh Pemahaman, Sanksi Perpajakan, dan Tingkat kepercayaan pada Pemerintah terhadap Kepatuhan Wajib Pajak dalam Membayar PBB-P2. Jurnal STEI Ekonomi, 28(02), 233-253. https://doi.org/10.36406/jemi.v28i02.253 